\title{
The Future of Post-Shoah Christology: Three Challenges and Three Hopes
}

\author{
Peter Admirand (1D
}

Citation: Admirand, Peter. 2021 The Future of Post-Shoah Christology: Three Challenges and Three Hopes. Religions 12: 407. https://doi.org/ $10.3390 /$ rel12060407

Academic Editors: Adam Gregerman and Philip Cunningham

Received: 27 April 2021

Accepted: 27 May 2021

Published: 2 June 2021

Publisher's Note: MDPI stays neutral with regard to jurisdictional claims in published maps and institutional affiliations.

Copyright: (C) 2021 by the author. Licensee MDPI, Basel, Switzerland. This article is an open access article distributed under the terms and conditions of the Creative Commons Attribution (CC BY) license (https:/ / creativecommons.org/licenses/by/ $4.0 /)$.
School of Theology, Philosophy, and Music, Dublin City University, Whitehall, Dublin 9, Ireland; peter.admirand@dcu.ie

\begin{abstract}
Post-Shoah Christology is embedded in the unique relationship of Jews and Christians, especially Jesus' Jewishness and the Jewish roots of Christianity, as well as Christian moral failures towards Jews before and during the Shoah. Essential for contemporary Christianity, a vibrant post-Shoah Christology confronts three main challenges, each demanding a different response. The first challenge is the reality that soon there will be no more first-generation witnesses to the Final Solution. Such is an inevitable challenge that has to be faced and prepared for. Religious pluralism is the second challenge, and includes a number of related threads, yet should ultimately be embraced. The third challenge is the (inevitable?) loss of memory, passion, and urgency, a willful forgetfulness by Christians towards the importance of the Jewish-Christian relationship, and especially, Christian failure in the Shoah. This challenge demands robust refutation and ongoing struggle. Before addressing these challenges, I will first further define and highlight the need for a post-Shoah Christology and will conclude this article with three general and three concrete hopes for a viable post-Shoah Christology.
\end{abstract}

Keywords: Shoah; Christology; post-Shoah Christology; religious pluralism; witness; genocide

\section{Introduction: Genocide and Christology}

Almost 90 years after Hitler's rise to power, in a predominantly Christian country, and the tepid response by a predominantly Christian Western World, the Shoah remains the main drive for Jewish-Christian dialogue. Initially, most Jews engaged with Christians to prevent another churban (using Ignaz Maybaum's term for destruction) (See Maybaum 2001, pp. 156, 165, 168 and 173). Christian motivation was more complex. Ideally, it sprung from repentance as well as fidelity to following Jesus, a 1st-century Jew from Nazareth whom Christians profess as God Incarnate. ${ }^{1}$ Subsequent benefits-mutual learning around Jesus or the wisdom of the rabbinic tradition-were secondary or unexpected fruits of the discussion. So, too, were calls for change, especially within Christian theology, and more specifically, Christology. Terms applied included "Christology after Auschwitz," (McGarry 1977) "Christology after the Holocaust," (Pawlikowski 1998, pp. 345-68) "a postHolocaust Christology," (Williamson 1993, p. 188) and the preferred term here, "post-Shoah Christology" (Moore 1993, p. 145).

Post-Shoah Christology is embedded in the unique relationship of Jews and Christians, especially Jesus' Jewishness and the Jewish roots of Christianity, as well as Christian moral failures towards Jews before and during the Shoah. As a term, it is intended to remind and encourage Christians of the contemporary importance of these truths. As this Christology is not just about the past, but essential for present and future Christianity, I see three main challenges to a vibrant post-Shoah Christology and each demands a different response.

The first challenge is the reality that soon there will be no more first-generation witnesses to the Final Solution. This will be an irreplaceable loss, especially as survivors have played an indelible role in calling many Christians to reassess their identity, responsibility, theological practices and doctrines, and need for deeper introspection. Nevertheless, this is an inevitable challenge that has to be faced and prepared for. 
Religious pluralism ${ }^{2}$ is the second challenge to a post-Shoah Christology and includes a number of related threads, including a rise in the nones and blended religious belonging, a growth in the range and types of interreligious dialogue and encounters, and a concurrent awareness of other mass atrocities (than the Shoah) and so seemingly competing memories, aims, and priorities. ${ }^{3}$ These related factors, taken together, can undermine the uniqueness and vitality of the Jewish-Christian relationship and so a post-Shoah Christology. Nevertheless, this challenge is best addressed as beneficial, as I will explain below.

The third challenge, and the one I most fear, is the (inevitable?) loss of memory, passion, and urgency, a willful forgetfulness by Christians towards the importance of the JewishChristian relationship, and especially, Christian failure in the Shoah. ${ }^{4}$ Such a forgetting and minimization could be linked to these first two challenges, but really exemplifies both the reason for a post-Shoah Christology, and more importantly, the existence of the Shoah itself. It is rooted in the amnesia and denial that have followed numerous mass atrocities in the past, and sadly, in our ongoing present.

Before addressing these challenges, I will first further define and highlight the need for a post-Shoah Christology. Looking to the future, I will conclude this article with three general and three concrete hopes for a viable post-Shoah Christology.

\section{Post-Shoah Christology}

Christian theologies of Jews and Judaism inevitably must consider the role of Christology in the formation of Christian attitudes towards the Jewish people and faith. Over the centuries, how Christians reflected upon Christ was entangled with their judgments and treatments of Jews. Sadly, Jesus' Jewishness was forgotten or downplayed. He was seen as condemning Jewish practices or breaking from Judaism and starting an entirely new religion or covenant. ${ }^{5}$ Such positions often had dire consequences not only for Jewish people, but for the integrity and fidelity of followers of Christ.

A post-Shoah Christology demands transformation and "sobering reassessment" 6 of anything intrinsic or extrinsic to Christian belief and practice that enabled, honed, or permitted the horrors of the Shoah against the Jewish people. Where crimes were committed, reparation to victims should also be supported. It entails a careful, but courageous re-examination, ${ }^{7}$ and where necessary, reformulation or condemnation, of complicit Christological dogma, scripture, theological writing, and papal pronouncements against Jews. The practice should be guided by a simple question: does such honor and do justice to the Jewishness of Jesus, the dignity and beauty of Jewish lives, and God's ongoing covenant with the Jewish people?

As a post-Shoah Christology informs, and is informed by, other Christologies, related but distinctive questions apply when ascertaining how and whether such beliefs uphold, for example, the option for the poor in a Christology of liberation theology, the equality and dignity of women in feminist Christologies (See especially Johnson 2007), the overcoming of anti-black racism of Christian practice in black liberation Christologies (Copeland 2019; See also Hayes 2014, pp. 153-63) or what Paul Hedges calls "antiracist and decolonial Christology (which "takes on board Jesus' Jewishness in a post-Holocaust context") (Hedges 2020, pp. 777-96). Consider also the turn to combat climate change in an ecological (See, for example, Pui-lan 1997, pp. 113-25) or green Christology (McDonagh 1999), or a Christology in the context of evolution (See, for example, Haight 2019, pp. 143 203). Again, such Christologies are united in their following of Jesus as an outpouring of Christian love, especially for the marginal, weak, and unprotected.

Some may fear that such questions would undermine or drastically alter Christian practice and power structures, rupturing links with foundations or sacred tradition. As love of God and love of neighbor are intertwined components in the Tanach and the Gospels (Matt 22:37-40), such questions also seem reasonable and faithful to such foundations and to sacred tradition.

Encased in Christ's exemplary witness to the potency of humility, empathy, and loving-kindness, a post-Shoah Christology should thus be a bit shell-shocked: uncertain, 
searching, and more apt to listen than pontificate. To say it is no longer triumphalist is only part of the truth. A post-Shoah Christology is a wounded and broken Christology, which reflects a wounded and broken Church and so a wounded and broken people. For Christians, belief in Christ crucified and resurrected remains a source of comfort, mending, and salvation.

It is also my conviction that recognizing our mutual brokenness, and so our need for one another, is a crucial step for healing, peace-spreading, and interfaith learning. A postShoah Christology, on the one hand, is still winged with the moral thrust and testimony of God incarnate who breaks bread with the poor and shameless (Matt 9:10-11; Luke 13:34; Isaiah 40:31; and Psalms 91:4). It shows us, and perhaps molds us, with a way to reach the heavens, to imitate holy divinity. Yet, that same Christology is tainted, chained, and bolted down through the noxious failures of Christ's followers, here in the context of the murder of six million Jews, but further sullied by systemic and sporadic Christian violation and violence against other marginal groups, including the Indigenous peoples throughout the world. Post-Shoah Christology remains only a half-measure without the expansion of such concerns, even as questions of the Shoah's uniqueness and historical importance must be addressed (see further below).

Sadly, few Christians are aware of a post-Shoah Christology. It is not a term that one finds in any Vatican or papal document or decree. A lived theology is more important than an articulated one, though, and here, perhaps, there is reason for hope, testifying to what Philip Cunningham calls "the story of a remarkable journey from antipathy and suspicion to a new, mutually enriching relationship between the two ancient traditions, Judaism and Christianity" (Cunningham 2015, p. ix). Jewish statements of a changed post-Shoah Christianity are evident in Jewish decrees like Dabru Emet and "To Do the Will of Our Father in Heaven," and is a refreshingly common statement in contemporary Jewish writing in the field of Jewish-Christian relations (Kessler 2010, pp. 1-2).

The contemporary archeology of the term can be traced from the urgent warnings and holy denunciations of Christian anti-Judaism by Jules Isaac, the tentative and muddled, but kinetic re-envisioning of Judaism in Nostra Aetate, ${ }^{9}$ and the work of theological trailblazers like Johann Baptist Metz, ${ }^{10}$ Gregory Baum (Baum 1977; 2018, pp. 32-38), David Tracy (See, for example, Tracy 1982, pp. 87-107; 1990, p. 4), John Pawlikowski, ${ }^{11}$ and the guidance and example of John Paul II in highlighting the Church's special relationship with Judaism and the Jewish people (See, for example, Admirand 2012b, pp. 555-75). The flowering of general interest in the Shoah further nuanced, challenged, and clarified the term. It also builds on the longer legacy of the marginal but potent Jewish interest in Jesus, especially after the Haskalah and early 20th-century Yiddish writings (see especially the novels of Scholem Asch). Of note, especially are engagement in Christology by Jewish-post-Shoah theologians from Emil Fackenheim's reminder that Jesus would have been murdered with his fellow Jews if alive during the time of National Socialism (Fackenheim 1994, p. 281) to Irving Greenberg's discussion of Jesus as a failed and not a false Messiah (Greenberg 2004, pp. 145-61). I also add Michael Kogan's bold invitation to fellow Jews to see Jesus, like the Torah, as the Christian way to God. ${ }^{12}$

Why, however, focus on a specifically post-Shoah Christology, and not a post-Gulag Christology (See, for example, Ryliškyte 2015, pp. 468-84) or a Christology in the context of genocide against the Acholi people of Northern Uganda and South Sudan, for example? (Whitmore 2019). Post-Nostra Aetate, Judaism, and especially Jewish-Christian dialogue has heralded a special theological status (Commission for Religious Relations with the Jews 2015, paras. 14, 15, 19, and 20), particularly in terms of the Jewish roots of Christianity, both biblically and Christologically. Some groups and contexts, however, may require or need another distinctive Christology (or Christologies), which is reasonable and understandable ${ }^{13}$ so long as those Christologies uphold the core issues applicable to a post-Shoah Christology, namely:

1. Disavowing supersessionism,

2. Promoting the dignity of the Jewish people, 
3. Taking responsibility for the history of Christian anti-Judaism,

4. Advocating valid interpretations of the Tanach through Jewish-only lenses,

5. Highlighting the ongoing viability of the Jewish covenant,

6. Recognizing the value of the Jewishness of Jesus, and

7. Ceasing Christian systemic attempts to convert the Jewish people (See Admirand 2016).

\section{When There Are No More Survivors: Challenge One}

Let me share a few personal stories. Approximately two years ago, while shopping in Lidl Supermarket with my then six-year-old son, I saw Tomi Reichental near the fruit and vegetables. We had participated in a few events together, so my greeting him was not untoward or some invasion of privacy, but it was intentional. I wanted my son to say hello. It would likely be the only in-person contact Ryan would ever have with a Shoah survivor. It, of course, meant nothing to Ryan then, and may only matter in the years ahead when I tell him: "You did meet a survivor when you were younger." That is why I did it. Such also were my motivations when I invited one of my older sons, Chris, to a pre-talk dinner I had arranged with Tomi. A few months later at my book launch, Tomi and his wife Joyce warmly greeted Chris, who then proudly introduced them to his mother and sister. Recently, Chris chose to do a major school history project on Tomi, carefully reading his biography, When I Was a Boy in Belsen.

A survivor of Bergen Belsen, Tomi has dedicated the last few decades of his life to speaking to as many students and schools as he can, recognizing he is one of the last of the witnesses. Born in Czechoslovakia in 1935, he is just old enough to retain some of his own memories, even as he acknowledges his stories and impressions also rely on older, fellow survivors.

Every Holocaust Memorial Day, the number of survivors is noticeably smaller, now mostly entailing those who were very young at the time like Tomi. As I write, I think about survivors who are no longer with us, from teachers of mine like Elie Wiesel (1928-2016) to writing collaborators like Philip Bialowitz (1925-2016), the last Jewish survivor of the Sobibor extermination camp. I fortuitously met Philip outside Warsaw's Museum of the History of Polish Jews. Striking up a conversation with him, I arranged his visit to my university a year or so later. He also wrote a preface for my edited book, Loss and Hope. I will never forget seeing him meet Tomi at an event I arranged as part of Philip's visit to Ireland with a local synagogue. There was an immediate connection; neither Tomi nor Philip knew one another, but it did not matter. They experienced horrors, and among themselves, there was no need for explanation or translation. It was all just understood. They laughed and joked, especially when recalling various honors and awards they had received.

Such banal or captivating moments, especially seeing Shoah survivors as real peopletelling jokes, sharing wisdom and tragic stories, connecting with a fellow survivor from a different camp, or bumping into a survivor while going shopping-will indeed soon be ever rarer. The personal, face-to-face encounter will not be possible. What has been, and what will be the effects of such losses? Will this only increase a minimization, or even denial, of the Shoah? The consequences for a post-Shoah Christology seem obvious.

This is a challenge, though, that must be responded to with creativity, humility, and resilience. Sometime, in the near future, we will read a newspaper article that the last living, primary witness to the Shoah has died. It will be a tragic loss, but as Elie Wiesel told us in class, in reading or hearing of the story of the witness, we are now witnesses. ${ }^{14}$ So, too, it is common at Shoah events to hear from the second or third generation of Shoah survivors. Such witnessing not only testifies to the reality of intergenerational trauma, but also the passing of the flame, an effort not only to keep the memory and stories of survivors alive, but to combat and prevent present and future ruptures.

Not having the gift of a living survivor before them, future classes will also benefit from AI and 3D hologram technology. For example, the USC Shoah Foundation's Dimensions in Testimony incorporates "advanced filming techniques [and] specialized display 
technologies" to enable "real-time responses from pre-recorded video interviews with Holocaust survivors and other witnesses to genocide." ${ }^{15}$ Reviews have been generally positive, but as Chris told me yesterday, "It won't be the same." He would know, but what of Ryan, or their younger sister, Mary?

While this first challenge must be soberly faced and addressed, the second challenge should be embraced as much as possible.

\section{Religious Pluralism: Challenge Two}

The second challenge to a viable post-Shoah Christology is linked by seemingly disparate strands which are conceptually and practically related, and when joined, could counter a vibrant post-Shoah Christology. The reality of religious pluralism has resulted in a diversification and expansion of interfaith dialogue, and also an increase in the nones, not just of atheists, but also those with little or no religious institutional belonging. It also includes those of a blended or multi-religious faith. This is not the space to examine why and how these developments have occurred, especially in the North Atlantic World, which may or may not be linked to the (once potent, but not fully debunked) secularization thesis. ${ }^{16}$ The result, especially among younger generations of Jews and Christians, though, seems to be a fluid, if not weak or rejected link, to institutional and communal Jewish or Christian identity.

Consider also the autonomous but related field of comparative genocide studies, where the Shoah is one of a number of historic mass atrocities, or simply the reality that different groups often have competing claims for advocacy, memory, praxis, and justice. Claims of unique and singular identity or narrowed moral projects, emblematic in Jewish-Christian dialogue and a post-Shoah Christology, would seem threatened, if not undermined, by such developments.

Building on the above, I see seven representative (but not exhaustive) "threats" in this challenge, which include

1. Remembering and advocating for other mass atrocities,

2. Supporting salvific truths and paths in multiple religions,

3. Engaging in other types of interfaith dialogues,

4. Opening up the Jewish-Christian dialogue to those of other faiths (usually Islam),

5. The growth of those who ascribe to a multi-religious or blended faith,

6. The rise of the nones who seem to have little institutional loyalty, belief, or firm religious identity,

7. The spread of atheism in the West, or a pervasive God and religion indifference, especially among the young.

These are all distinct but interrelated points that seem to align in deprioritizing the Shoah or eroding the passion and focus needed to sustain and defend the necessity of a specifically and uniquely Jewish-Christian dialogue and engagement. Either erosion also disempowers a post-Shoah Christology.

Reflecting on the points above opens the floodgates to further doubts on how and whether the study of the Shoah and the related impetus to nurture and engage in JewishChristian dialogue will be sustained by a sufficient number of people in the future.

Some further pertinent questions or provocative statements may include

1. What about the gulags, laogai, Cambodian killing fields, Syria, the wars in the Democratic Republic of Congo? What about the millions of poor and malnourished, stuck in slums and ghettos? What about refugees and migrants, dying at our borders and in our seas?

2. The more urgent issue is Islam, especially after $9 / 11$ and the ongoing rise and threat of Islamic fundamentalism.

3. Many scholars believe the future of Christianity (especially in terms of numbers) will be in the Global South, especially Africa, where limited contact with living Judaism (but growing tension with Islam), raises its own problems. In such contexts, other mass atrocities (like the Rwandan Genocide) also seem a more pressing and relevant. theological and moral challenge. What, again, becomes of a post-Shoah Christology? 
4. There is no one way: people can believe what they do as long as they do not harm anyone. Judaism is meaningful for you, while I find holiness through Christianity, perhaps even in some combination.

5. Jewish-Christian dialogue, like the Christian ecumenical movement, has gone as far as it can right now. Deeper possibilities and new interfaith territory are found in other faiths like Buddhism. Emily Sigalow, in American JewBu, for example, notes younger Jewish interest in Buddhism as a religion because it is clearly different from Judaism (as well as Christianity and Islam), with little (negative) history with Jewish lives and well-being (Sigalow 2019, p. 172).

6. "I am not a practicing Jew." "I was raised Catholic, but I don't really follow that anymore."

7. What about the Palestinian people and how they are treated by the State of Israel? ${ }^{17}$ How can you support the Church with its views on women or especially after the child abuse atrocities committed, abetted, and silenced by clerics?

The above only touches upon the sense of potential threats to a viable future for JewishChristian dialogue principally, and secondarily, the world's still thriving fascination with the Shoah. Again, sustaining a post-Shoah Christology, in light of such objections, is daunting.

Not all of these threads and questions can be comprehensively addressed here, so I will limit myself, first, to the question of the Shoah and other genocides and then discuss how my conception of God (reflected in my post-Shoah Christology) influences and responds to the challenge of religious pluralism.

\section{The Shoah and Other Atrocities}

In I You We Them, Dan Gretton's harrowing and exhaustive account of the desk killer (Schreibtischtaeter) across mass atrocities (Gretton 2019, pp. 30-31), he not only shows how corporations and various tiers of society have played pivotal roles in implementing genocides, but also how these processes, ideologies, technocratic bureaucracies, and torture techniques were influenced and developed by previous and subsequent regimes. Consider, for example, the systemic violence and practices Germans unleashed on the Herero people in the early 20th century and the related and lethal modifications then employed in the Final Solution. ${ }^{18}$ As Ben Kiernan has argued in Blood and Soil, studying and comparing mass atrocities are a means not only to see how these genocidal onslaughts are interrelated, but more importantly, to identify common signals and attributes to recognize a likely eruption of genocidal violence so it can be thwarted (Kiernan 2007). Or, as Michael Rothberg notes, a multi-directional memory, in which we study and remember a variety of mass atrocities, can enhance, and not diminish, commitment to a specific cause (Rothberg 2009). Echoing Kiernan, Wolf Gruner argues how the study of other mass atrocities "helps us to challenge and revise assumptions about the Holocaust... But especially in the past fifteen years, scholars have demonstrated how genocidal societies develop similar concepts of homogenization, tools of persecution, and forms of mass murder" (Gruner 2021, pp. 15566). Likewise, in the context of wars depicted in graphic novels, Tatiana Prorokova and Nimrod Tal rightfully point out that examining so-called small conflicts, and not just largescale wars," reveals how "a deep, nuanced look at the periphery allows one to take a fresh look at the center" (Prorokova and Tal 2018, pp. 1-19). Such views need not, for example, threaten claims of the Shoah's uniqueness or historical and moral role. More importantly, they honor and remember its victims. Yet, concern of an erasure of memories or priorities (even while recognizing the rights of survivors of other atrocities) is understandable.

Such fear of erasure and uniqueness is also evident in the context of religious pluralism.

\section{Religious Pluralism and a Post-Shoah Christology}

In a recent paper, I anguished over whether to profess that Jesus was "superfluous" for Jews (See Admirand 2020, pp. 1-22; See also Berger et al. 2008, pp. 124 and 180-81; Rutishauser 2011, pp. 229-50). The challenge came from a statement by Jewish theologians 
Alan Berger and David Patterson that I wanted to answer based on post-Vatican II Catholic presentations and beliefs about Judaism, and discontent about the advice simply to suspend eschatological judgments on the issue until the eschaton. Privately, I reflected how there could not be just one way towards ultimate meaning, or in my language, God. Human beings, despite many common traits, were too wildly diverse, and ultimately, God is a mystery, unable to be boxed and contained by human conceptions and theologies. Or rather, my God is vehemently loving, playful, and demanding - tensions not easy to extricate, or perhaps articulate lucidly, but pertinent to my conception of post-Shoah Christology.

If God is not love-pervasively, obsessively, and purely loving - then there is no God. It is this trait, in the theodicy problem, that few of us would compromise. Of God's justice, for which I yearn and desperately want to believe, this world reveals contradictions and enigmas, and in moments like the Shoah, despairing silence. But love is the bedrock of any lasting covenant or relationship with God, the most important ingredient for prayer, and the key attribute for us to imitate and mirror attempts to express our image and likeness in God. How we understand and incorporate a loving God of justice remains the most perplexing and arduous theological task, demanding theological protest, or what Elie Wiesel calls "wrestling with God."

Jesus emphasized how we must be like children (Matt 18:3), ${ }^{19}$ and perhaps, such wrestling is applicable here, too. If being childlike means to be carefree, curious, empathic, imaginative, and joyful, they are also appealing traits in a Deity of creation, borne out by its strangeness, magnanimity, humor, and profundity. As Creator, such a Being would expect us to uphold and support creation's aim of flourishing and to manifest divine presence in this world through exercising our freedom and responsibility to heal and create one another (Genesis 1:28). Thus, my conception of God is starkly moral, and here is where the Jesus of the Gospels guides and sustains me, especially his stories and parables of hospitality and forgiveness (Luke 14:12-14, Luke 19:5, and Mark 14:3-9); mending of the broken and lost (Mark 3:1-6, Mark 5:21-43, Luke 15:3-7, and John 9:1-7); commitment to truth and nonviolence (Matt 26:52, Matt 5:44, and John 8:1-11); and integrity and love of others (Mark 12:30-31, John 14:23, and John 15:13).

Is that the Jesus I was saying is "superfluous?" Hence, my anguish and guilt. Then, I thought of my children, especially the teenage ones. They are unbothered by such concerns. There are various reasons for this indifference, but much of it is rooted in a basic sense that as long as you are trying to be good and think of others, especially the most vulnerable, then these other "religious" issues do not really matter. In this sense, they are emblematic of the rise of the nones who have little sense of institutional belonging, may or may not believe in God, only sporadically think of the question, or are trying out different paths of meaning.

Such issues need further reflection for their impact on Jewish and Christian identity and so any robust Jewish-Christian dialogue, let alone a post-Shoah Christology. Nevertheless, I see great potential for further development here. In the same article, for example, I highlighted my support and pedagogical practice of teaching an interfaith Christology (Phan 2017, pp. 91-98), namely how Christ is conceived and taught by non-Christians. Such contact, exposure, and scope, I contend, has discomfited but also cleansed and refined Christology. As noted above, I include Jewish interpretations as a key part of both a post-Shoah and interfaith Christology.

Wider exposure need not annul identity. In Dabru Emet, for example, we read how Jews should not feel their faith and identity will be threatened by engaging in JewishChristian dialogue. ${ }^{20}$ A similar claim applies to expanding the interfaith conversation or the study of other genocides. The deeper and wider the exploration of various paths and exposure to the distinctive challenges and questions raised from different positions, the more our own traditions can be humbled, enlightened, checked, and strengthened, and the more our distinctive dialogues can be refined, evaluated, and improved.

One final, practical point: just as there is scope for multi-religious conversations, like dialogues among Hindus, Muslims, and Sikhs, there is also need for more selective and 
focused conversations. Both exclusive and expansive dialogue platforms can support one another. For example, a Buddhist-Jewish-Christian dialogue (See, for example, Cobb and Ives 2005) will present questions, issues, and insights that may otherwise not have occurred in an International Council of Christians and Jews gathering. Likewise, the rich history of Jewish-Christian dialogue has much to teach other dialogues on what has or has not worked. Christology, as I noted above, is richly strengthened by interreligious (and interdisciplinary) engagement. Thus, while religious pluralism can still be seen as a threat to a post-Shoah Christology, it ultimately should be embraced.

The third and final challenge, however, demands vigilance and ongoing struggle.

\section{Amnesia, Denial, Indifference: Challenge Three}

In July 1939, Eva Paddock, then three-and-a-half years old, boarded the last Kindertransport ${ }^{21}$ from Prague to the UK. The rescue operation was organized by Nicholas "Nicky" Winton, a young British banker. There was supposed to have been one more train. All the children were scheduled to leave, but then war erupted and the train could not depart. It is believed none of those children survived.

As part of my university's postgraduate module on the Holocaust, I invited Eva to share her story in the late spring of 2021. While via ZOOM, it had all the spontaneity and shared humanity that make such real-time events memorable. Eva's account is riveting, especially bulwarked by historical family heirlooms (like the olive-green ruck sack, tattered luggage tag, and stamped ID card she brought with her on the train journey). There was even unexpected levity: at one point Eva had to let her dog outside, and one participant, while formulating a question, was asked by Eva to show his parrot, squawking loudly in the background.

Kaitlyn, my 13-year-old daughter, who sat next to me during the talk, later beamed: "She is such a good speaker." Eva's story is also remarkable because of the many kind people who helped her-and later assisted her parents, including remarkably, a member of the SS. Will these stories be remembered, and are they enough to forestall or stop future ruptures? Such, again, is the main reason survivors of the Shoah, and of all mass atrocities, serve as witnesses.

Returning to Gretton's book above, in which the Shoah performs a foundational role of witness, at one point he wonders if the world's fascination with the Shoah (especially considering the American context) is to provide a clear narrative of us and them, with the Nazis performing the unvarnished role of evil doer, and the Allies, the heroes and good guys. Gretton, born and based in the United Kingdom, also wonders if this fascination is a cover for his own nation's complicity in atrocities and even contributions to National Socialism. He uncovers, for example, how UK and other European banks and global corporations supported and funded the Nazi Party's nascent rise to power. Such is a disconcerting idea-that focus on the Shoah can displace moral responsibility and roles in other genocides. Gretton quotes Günter Grass: “I sometimes wonder how young people grow up in Britain and know so little about the long history of crimes during the colonial period. In England, it's a completely taboo subject." 22

Amnesia towards past and present atrocities and injustice is our third and most difficult challenge to a viable post-Shoah Christology. The Shoah was not an isolated rupture. As noted, it was nurtured by the long history of anti-Judaism in Christianity. It is also linked to why a peasant carpenter from Galilee was betrayed, tortured, and crucified, why Uighur Muslims are presently sent to reeducation camps in China, why urban African American youth are more likely to experience poverty, die from Covid, and have a criminal record than White Americans, or why a child in Yemen, El Salvador, or Uganda is far more likely to die of malnutrition, preventable disease, or violence than native-born children in Northern Europe.

Systemic violence, power-grabs for land, status, or resources, authoritarian protection and enforcement of ethnic, national, class, or religious privilege- the reasons can be varied, but entail a denial of the equal value, dignity, and beauty of fellow human beings. 
Christology, regardless of the descriptor or adjective placed before it, should seek to overcome and heal those denials and divisions. It is Christ himself who asks us to remember core truths of communion and service (Luke 22:19 and Matt 26:13). Unfortunately, many Christians have invoked Jesus in the name of violence and inequality, and in denying responsibility for atrocities. Can deeper awareness of past atrocities and the need for interfaith partnership quell such failures?

\section{Conclusions: Three Hopes for Post-Shoah Christology}

Advocating for a Post-Shoah Christology is really to demand an acceptance and sober humbling from the failures of Christian life, practice, and belief, not only during the years of 1933-1945, but in the many related steps and stages that led to that cataclysmic rupture-all the anti-Jewish slander, whether biblical, homiletic, literary, or casual; the sporadic, unaddressed violence; the pogroms and displacements, forced exiles, and the legal and cultural anti-Judaic decrees; and the general apathy during and immediately after the war. Such a Christology, seeing the Shoah as both lived history and entwined with other genocides and mass atrocities, still demands revision and reassessment. As I have argued elsewhere, the abuse of children by Catholic clerics, and more damning, the institutional silence and cover-up, was an almost inevitable outcome of the earlier violence and silencing of "the other" (the heretic, Jew, Muslim, Native American, Black slave) eventually turning ever inward, from so-called outsiders to those innocent loved ones in our midst (See Admirand 2014, pp. 123-36).

What makes the Shoah so humbling for Christians (and destructive for Jews) was the depth and extent of the moral failure. Speaking as a Catholic, what would a Church (guided by a post-Shoah Christology) look like if we responded to these challenges honestly and seriously? I conclude with three general (and three concrete) hopes.

1. Ongoing repentance and humility (Matt 3:2 and Matt 5:5) by expressing clear Church responsibility for past and present institutional moral failures.

- Such would include a revision and update of "We Remember-A Reflection on the Shoah," outlining specifically the moral failures of the Church towards the Jewish people before and during the Shoah (and so not separating the sacramental status/role of the Church as the Body of Christ with the immoral actions of certain Christians).

2. Commitment to deeper interreligious listening and learning (Mark 7:24-30), and thus, minimally, a movement towards religious pluralism.

- This hope entails an expansive update of Nostra Aetate, emphasizing Christianity's learning from Judaism and the meaning of God's ongoing covenant with the Jewish people (in the context of this article) and deeper inclusion of the value of other world faiths and Indigenous religions. Note that updating and rebuking Church documents countering these attempts should also be undertaken, including contemporary documents like Dominus Iesus.

3. Incorporating testimonies of victims of the Shoah and other mass atrocities within Church masses, catechesis, and theological and seminary classes.

- Here I follow Rabbi Anson Laynter's highlighting of Jewish theological protest within Jewish liturgy (See Laytner 2019). Such protest would also align with prioritizing the Franciscan view of the Atonement (See Admirand 2008, pp. 30217) (Jesus came purely from love, even as such love often leads to the cross because of the sinfulness of the world). This view of the Incarnation would not only purify and fortify a post-Shoah Christology but Jewish-Christian relations and the Christian hope for salvation through other holy paths. ${ }^{23}$

These hopes are only traces of a wider Christian witness. They should be in service towards systemic and structural change best embodied in Jesus' teaching the disciples about God's will: "on earth as it is in heaven" (Matt 6:10). A commitment to a post-Shoah Christology can help manifest and renew such a prayer and reign. 
Funding: This research received no external funding.

Acknowledgments: I thank Didier Pollefeyt and Dermot Lane for their careful reading and encouragement of an earlier draft.

Conflicts of Interest: The author declares no conflict of interest.

\section{Notes}

1 I thank Phil Cunningham for reminding me to go beyond "merely a guilt driven response for Christian engagement with Jews to the Shoah." Motivation instead should come from Christian witness of following Christ that leads to relationship with the Jewish people and facing the horrors of the Shoah. Cunningham notes this more lasting motivation in analysis (with Adam Gregerman) of recent (and controversial) writings of Pope Emeritus Benedict XVI. See (Cunningham and Gregerman 2019).

2 For my analysis of the types, limits, and strengths of religious pluralism, see (Admirand 2019, chp. 3). See also (Thatamanil 2020).

3 The field of interreligious studies (and related groups or subgroup) is ever-expanding, but see for example, (Gustafson 2020). On the expansion and diversification of interreligious dialogue, see (Cornille 2013). For a recent key text embracing religious pluralism (as echoed in nature) through interreligious theology, see (Schmidt-Leukel 2017); and for a helpful edited collection analyzing the text (with Schmidt-Leukel's response), see (Race and Knitter 2019).

4 Confer, especially, the writing of James Baldwin on White silence, forgetfulness, denial, and amnesia towards mistreatment, social injustice, and structural racism in American society. I write on these themes in (Admirand 2019, chp. 6).

5 I thank Phil Cunningham for helping me formulate this preamble.

6 (Boys 2000, p. 73). See also Didier Pollefeyt's collection of essays and reflections on theology and the Shoah, especially his classic essay (Pollefeyt 2018, pp. 255-77); and (Meyer 2020, pp. 102-3).

7 Marianne Moyaert writes: "In light of the tragedy of the Holocaust, Christian theology has an ethical responsibility to re-examine its Christology." See Marianne Moyaert, "Who is the Suffering Servant? A Comparative Theological Reading of Isaiah 53 after the Shoah." In (Moyaert 2016, pp. 216-37).

8 Initially, some liberation theological texts were rebuked for supersessionist understanding. Note that much of my work draws on both liberation and post-Shoah theology. See (Admirand 2012c, chps. 6-9; Admirand 2018, pp. 156-69).

9 In a recent article, Didier Pollefeyt, for example, has argued that despite recent gains in Jewish-Christian dialogue, "the Catholic Church does not have a clear and consistent theology of Judaism" which can uphold the unrevoked Jewish covenant with God and the "unique and universal meaning of Christ." See (Pollefeyt 2020, pp. 483-98). See especially Metz's essays (Metz 1995a, pp. 38-48; Metz 1995b, pp. 3-16). See also (Manemann 2001, pp. 775-87). A foundational text is (Pawlikowski 1982, pp. 136-47). See also (Pawlikowski 2007, pp. 147-67).

12 Though resembling the Christian heresy of adoptionism, Kogan's attempt also resonates with the Orthodox Christian belief of theosis. See (Kogan 2018, pp. 73-93). For my assessment of Jewish critiques of Christology, see (Admirand 2016, pp. 81-96).

13 Writing in 2004, (Phan 2004, p. 162).

14 See, for example, (Burger 2019, p. 269). For my account of witness testimonies and their indispensable role for theology and theodicy, see (Admirand 2012c, chp 3).

15 USC Shoah Foundation. Homepage. https:/ / sfi.usc.edu/dit, accessed on 15 May 2021. For evaluation of “Germanspeaking digital interactive Holocaust testimony," see (Kolb 2021, pp. 63-82). See also (Fishbane 2020).

16 See, for example, (Taylor 2007) and my analysis of the secular and secularities in (Admirand 2019, chp. 5).

17 Regarding the Land of Israel in the context of Jewish-Christian dialogue, see (Cunningham et al. 2020). This is a convenient place to add, though the present article does not allow me to develop this adequately, that Christian Palestinian voices are also needed to further nuance (and complicate) my claims about the need for a post-Shoah Christology.

18 Gretton, I You We Them, pp. 541-601. See also (Lindqvist 2007).

19 For my account of the mixed biblical legacy of children in the Gospels, see (Admirand 2012a, pp. 187-95).

20 "A new relationship between Jews and Christians will not weaken Jewish practice." (Dabru Emet 2000).

21 For an account of the Kindertransport, see, for example, (Craig-Norton 2019). Eva's talk can be accessed via Youtube here: https: / / www.youtube.com/watch?v=bfReG66mCNA, accessed on 15 May 2021. 
23 An initial draft of this article had included a comment (in the context of the Incarnation) against a God demanding blood or sacrifice. An anonymous reviewer rightly reminded me of the old anti-Christian trope disconnecting the God of Christianity with the God of the Tanakh, whose worship included the ritual of Temple sacrifice. The reviewer helpfully recommended (Halbertal 2015), noting Halbertal "points out that the sacrifices (Hebrew qorbanot) were meant to bring people closer to God (and 'to be close' is the root meaning of Q-R-B)." Regarding Jesus and Temple Sacrifice, I remain somewhat ambivalent. I note how Mary and Joseph offered sacrifice at the Temple during Jesus' Presentation (Luke 2:22-24), a young Jesus taught there (Luke 2:46), and an older Jesus (before his arrest) noted he often preached in the Temple (Matt 26:55). Most pertinent is the cleansing of the Temple, principally against the money lenders (Mark 11:15-19 and John 2:13-16), but note how he also drove out the "sheep and oxen" from the Temple (John 2:15). What happened to those animals after this incident?

\section{References}

Admirand, Peter. 2008. Healing the Distorted Face: Doctrinal Reinterpretation(s) and the Christian Response to the Other. One in Christ 42: 302-17.

Admirand, Peter. 2012a. Millstones, Stumbling Blocks, and Dog Scraps: Children in the Gospels. Biblical Theology Bulletin 42: 187-95. [CrossRef]

Admirand, Peter. 2012b. Rifts, Trust, and Openness: John Paul II's Legacy in Catholic Intra-and-Interreligious Dialogue. Journal of Ecumenical Studies 47: 555-75.

Admirand, Peter. 2012c. Amidst Mass Atrocity and the Rubble of Theology: Searching for a Viable Theodicy. Eugene: Cascade Books.

Admirand, Peter. 2014. The Pedophile Scandal and Its (Hoped-for) Impact on Catholic Intra-and Interreligious Dialogue. In Loss and Hope: Global, Interreligious, and Interdisciplinary Perspectives. Edited by Peter Admirand. London: Bloomsbury, pp. $123-36$.

Admirand, Peter. 2016. Landmines and Vegetables: The Hope and Perils of Recent Jewish Critiques of Christianity. In Pathways for Interreligious Dialogue. Edited by Vladimir Latinovic, Gerard Mannion and Peter Phan. New York: Palgrave, pp. 81-96.

Admirand, Peter. 2018. Multiple Liberations: Why Liberation Theology Should Be Taught in Catholic Secondary Schools. International Studies in Catholic Education 10: 156-69. [CrossRef]

Admirand, Peter. 2019. Humbling Faith: Brokenness, Doubt, Dialogue-What Unites Atheists, Theists, and Nontheists. Eugene: Cascade Books.

Admirand, Peter. 2020. Following the Breadcrumbs: Jesus as Superfluous to Salvation? A Catholic Search. SCJR 15: 1-22. [CrossRef]

Baum, Gregory. 1977. Christian Theology after Auschwitz. London: Council of Christians and Jews.

Baum, Gregory. 2018. The Oil Has Not Run Dry: The Story of My Theological Pathway. Montreal: McGill-Queens's University Press.

Berger, Alan L., David Patterson, David P. Gushee, John T. Pawlikowski, and John K. Roth. 2008. Jewish-Christian Dialogue: Drawing Honey from the Rock. St. Paul: Paragon House.

Boys, Mary C. 2000. Has God Only One Blessing? Judaism as a Source of Christian Self-Understanding. Mahwah: Paulist Press.

Burger, Ariel. 2019. Witness: Lessons from Elie Wiesel's Classroom. Boston: Mariner Books.

Cobb, John B., and Christopher Ives, eds. 2005. The Emptying God: A Buddhist-Jewish-Christian Conversation. Eugene: Wipf \& Stock.

Commission for Religious Relations with the Jews. 2015. 'The Gifts and the Calling of God Are Irrevocable' (Rom 11:29): A Reflection on the Theological Questions Pertaining to Catholic-Jewish Relations on the Occasion of the 50th Anniversary of 'Nostra Aetate' (No. 4) (10 December 2015). Available online: http://www.vatican.va/roman_curia/pontifical_councils/chrstuni/relationsjews-docs/rc_pc_chrstuni_doc_20151210_ebraismo-nostra-aetate_en.html (accessed on 15 May 2021).

Copeland, M. Shawn. 2019. Knowing Christ Crucified: The Witness of African American Religious Experience. New York: Fordham University Press.

Cornille, Catherine, ed. 2013. The Wiley-Blackwell Companion to Inter-Religious Dialogue. Oxford: Wiley-Blackwell.

Craig-Norton, Jennifer. 2019. The Kindertransport: Contesting Memory. Bloomington: Indiana University Press.

Cunningham, Philip A. 2015. Seeking Shalom: The Journey to Right Relationship between Catholics and Jews. Grand Rapids: Eerdmans.

Cunningham, Philip A., Ruth Langer, and Jesper Svartvik, eds. 2020. Enabling Dialogue about the Land: A Resource Book for Jews and Christians. Mahwah: Paulist Press.

Cunningham, Philip, and Adam Gregerman. 2019. 'Genuine Brotherhood' without Remorse: A Commentary on Joseph Ratzinger's 'Comments on 'De Iudaeis'. Studies in Christian-Jewish Relations 14: 1-29. Available online: https://ejournals.bc.edu/index.php/ scjr/article/view/11925/9823 (accessed on 15 May 2021). [CrossRef]

Dabru Emet. 2000. Dabru Emet: A Jewish Statement on Christians and Christianity, Institute for Islamic-Christian-Jewish Studies (10 September 2000). Available online: https:/ /icjs.org/resources/dabru-emet (accessed on 15 May 2021).

Fackenheim, Emil. 1994. To Mend the World: Foundations of Post-Holocaust Jewish Thought. Bloomington: Indiana University Press.

Fishbane, Matthew. 2020. Do Holocaust Survivors Dream of Electric Sheep? Tablet. April 21. Available online: https://www.tabletmag. $\mathrm{com} /$ sections/arts-letters/articles/dimensions-in-testimony-holocaust-survivors (accessed on 15 May 2021).

Greenberg, Irving. 2004. For the Sake of Heaven and Earth: The New Encounter between Judaism and Christianity. Philadelphia: Jewish Publication Society.

Gretton, Dan. 2019. I You We Them: Journeys beyond Evil: The Desk Killers in History and Today. London: William Heinemann, vol. 1. 
Gruner, Wolf. 2021. My Unorthodox Path: Toward Integrative, Interdisciplinary, and Comparative Holocaust Studies. In Advancing Holocaust Studies. Edited by Carol Rittner and John K. Roth. Abingdon: Routledge, pp. 155-66.

Gustafson, Hans, ed. 2020. Interreligious Studies: Dispatches from an Emerging Field. Waco: Baylor University Press.

Haight, Roger. 2019. Faith and Evolution: A Grace-Filled Naturalism. Maryknoll: Orbis.

Halbertal, Moshe. 2015. On Sacrifice. Princeton: Princeton University Press.

Hayes, Diane L. 2014. Christology in African American Theology. In The Oxford Handbook of African American Theology. Edited by Anthony B. Pinn and Katie G. Cannon. Oxford: Oxford University Press, pp. 153-63.

Hedges, Paul. 2020. White Jesus and Antisemitism: Toward an Antiracist and Decolonial Christology. The Ecumenical Review 72: 777-96. [CrossRef]

Johnson, Elizabeth. 2007. Quest for the Living God: Mapping Frontiers in the Theology of God. New York: Continuum.

Kessler, Edward. 2010. An Introduction to Jewish-Christian Relations. Cambridge: Cambridge University Press.

Kiernan, Ben. 2007. Blood and Soil: A World History of Genocide and Extermination from Sparta to Darfur. New Haven: Yale University Press.

Kogan, Michael. 2018. Welcoming Jesus Home. In Righting Relations after the Holocaust and Vatican II: Essays in Honor of John T. Pawlikowski, OSM. Edited by Elena G. Procario-Foley and Robert A. Cathey. Mahweh: Paulist Press, pp. 73-93.

Kolb, Daniel. 2021. Evaluation of the Interaction with a Digital 3D Testimony. Between Emotion and Technology. In Interaktive 3D-Zeugnisse von Holocaust-Überlebenden. Chancen und Grenzen einer Innovativen Technologie. Edited by Anja Ballis, Markus Gloe, Florian Duda, Fabian Heindl, Ernst Hüttl, Daniel Kolb and Lisa Schwendemann. Braunschweig: Georg-Eckert-Institut für internationale Schulbuchforschung, vol. 1, pp. 63-82.

Laytner, Anson Hugh. 2019. The Mystery of Suffering and the Mystery of God: Autobiographical and Theological Reflections. Eugene: Resource Publications.

Lindqvist, Sven. 2007. 'Exterminate All the Brutes': One Man's Odyssey into the Heart of Darkness and the Origins of European Genocide. New York: New Press.

Manemann, Jurgen. 2001. Jews and Christians after Auschwitz. In Remembering for the Future. Edited by John K. Roth and Elisabeth Maxwell. 3 vols. London: Palgrave Macmillan, vol. 3, pp. 775-87. [CrossRef]

Maybaum, Ignaz. 2001. Ignaz Maybaum: A Reader. Edited by Nicholas de Lange. New York: Berghahn.

McDonagh, Seán. 1999. Greening the Christian Millennium. Dublin: Dominican Publications.

McGarry, Michael B. 1977. Christology after Auschwitz. Ramsey: Paulist Press.

Metz, Johann Baptist. 1995a. Facing the Jews: Christian Theology after Auschwitz. In Johann-Baptist Metz and Jürgen Moltmann, Faith and the Future: Essays on Theology, Solidarity, and Modernity. Translated by John Griffiths. Nijmegen: The Concilium Foundation, pp. 38-48.

Metz, Johann Baptist. 1995b. The Future in the Memory of Suffering. In Johann-Baptist Metz and Jürgen Moltmann, Faith and the Future: Essays on Theology, Solidarity, and Modernity. Translated by John Griffiths. Nijmegen: The Concilium Foundation, pp. 3-16.

Meyer, Barbara U. 2020. Jesus the Jew in Christian Memory: Theological and Philosophical Exploration. Cambridge: Cambridge University Press.

Moore, James F. 1993. Christian Theology after the Shoah. Lanham: University of America Press.

Moyaert, Marianne. 2016. Who Is the Suffering Servant? A Comparative Theological Reading of Isaiah 53 after the Shoah. In Comparing Faithfully: Insights for Systematic Theological Reflections. Edited by Michelle Voss Roberts. New York: Fordham University Press, pp. 216-37.

Pawlikowski, John T. 1998. Christology after the Holocaust. Encounter 59: 345-68.

Pawlikowski, John. 1982. Christ in the Light of Jewish-Christian Dialogue. Ramsey: Paulist Press.

Pawlikowski, John. 2007. Christology and the Jewish-Christian Dialogue: A Personal Theological Journey. The Irish Theological Quarterly 72: 147-67. [CrossRef]

Phan, Peter. 2004. Being Religious Interreligiously: Asian Perspectives on Interfaith Dialogue. Maryknoll: Orbis.

Phan, Peter. 2017. The Joy of Religious Pluralism: A Personal Journey. Maryknoll: Orbis Books.

Pollefeyt, Didier. 2018. Ethics and Theology after the Holocaust. Leuven: Peeters Press.

Pollefeyt, Didier. 2020. Unrevoked Covenant-Revoked Consensus-Indestructible Love? The Reception of Nostra Aetate 4 in Jewish-Catholic Relations. In 'Res opportunae nostrae aetatis': Studies on the Second Vatican Council Offered to Mathijs Lamberigts. Edited by Dries Bosschaert and Johan Leemans. Louvain: Peeters Press, pp. 483-98.

Prorokova, Tatiana, and Nimrod Tal. 2018. Introduction. In Cultures of War in Graphic Novels: Violence, Trauma, and Memory. Edited by Tatiana Prorokova and Nimrod Tal. Rutgers: Rutgers University Press, pp. 1-19.

Pui-lan, Kwok. 1997. Ecology and Christology. Feminist Theology 5: 113-25. [CrossRef]

Race, Alan, and Paul Knitter, eds. 2019. New Paths for Interreligious Theology: Perry Schmidt-Leukel's Fractal Interpretation of Religious Diversity. Maryknoll: Orbis.

Rothberg, Michael. 2009. Multidirectional Memory: Remembering the Holocaust in the Age of Decolonization. Stanford: Stanford University Press.

Rutishauser, Christian. 2011. 'The Old Unrevoked Covenant' and 'Salvation for All Nations in Christ': Catholic Contradictions? In Christ Jesus and the Jewish People Today: New Explorations of Theological Interrelationships. Edited by Philip A. Cunningham, Joseph Sievers, Mary C. Boys, Hans Hermann Henrix and Jesper Svartvik. Grand Rapids: Eerdmans, pp. 229-50. 
Ryliškytė, Ligita. 2015. Post-Gulag Christology: Contextual Considerations from a Lithuanian Perspective. Theological Studies 76: 468-84. [CrossRef]

Schmidt-Leukel, Perry. 2017. Religious Pluralism and Interreligious Dialogue: The Gifford Lectures—An Extended Edition. Maryknoll: Orbis. Sigalow, Emily. 2019. American JewBu: Jews, Buddhists, and Religious Change. Princeton: Princeton University Press.

Taylor, Charles. 2007. A Secular Age. Cambridge: Harvard University Press.

Thatamanil, John J. 2020. Circling the Elephant: A Comparative Theology of Religious Diversity. New York: Fordham University Press.

Tracy, David. 1982. Religious Values after the Holocaust: A Catholic View. In Jews and Christians after the Holocaust. Edited by Abraham J. Peck. Philadelphia: Fortress Press, pp. 87-107.

Tracy, David. 1990. Dialogue with the Other: The Inter-Religious Dialogue. Louvain: Peeters Press.

Whitmore, Todd D. 2019. Imitating Christ in Magwi: An Anthropological Journey. London: T\&T Clark.

Williamson, Clark. 1993. A Guest in the House of Israel: Post-Holocaust Church Theology. Westminster: John Knox Press. 